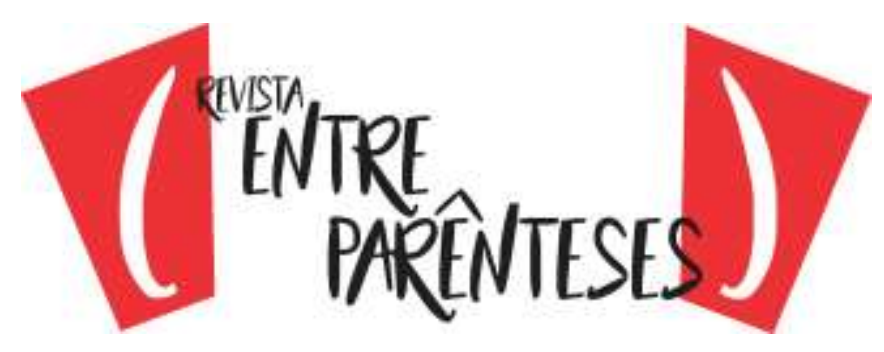

\title{
UMA LOUCURA E DUAS REALIDADES EM JOHN GABRIEL BORKMAN, DE HENRIK IBSEN
}

https://doi.org/10.32988/rep.v1n9.1123

\author{
Vicentonio Regis do Nascimento ${ }^{1}$ \\ (vicrenos@yahoo.com.br)
}

\begin{abstract}
Resumo: Henrik Ibsen é o fundador do drama moderno. Conhecido pela escrita de Casa de bonecas - em que impulsiona a liberdade feminina, com a personagem principal saindo da casa da família e enfrentando o mundo externo, o qual não é apresentado ao leitor/espectador - Ibsen dedica-se a focalizar, em John Gabriel Borkman, duas mulheres afundadas em suas realidades particulares, pessoais e imutáveis, em torno da loucura fantasiosa do homem que dá título à peça. Este artigo pretende mostrar como, nesse drama, diferentemente de em Casa de bonecas, a dualidade feminina da realidade depende exclusivamente da loucura masculina, assim como as sombras dependem da vela.
\end{abstract}

Palavras-chave: Ibsen; feminino; drama moderno.

\section{ONE MADNESS AND TWO REALITIES IN JOHN GABRIEL BORKMAN, BY HENRIK IBSEN}

Abstract: Henrik Ibsen is the founder of modern drama. He wrote Doll's house - a play which projects female freedom with a protagonist leaving her family house and discovering a new world, this new world is not shown to reader/spectator - lbsen shows us, in John Gabriel Borkman, two women lost in their particular, personal and immutable realities around a madness fantasy of a male character who intitules this master-piece. This article intends to show how double reality of the female needs exclusively a male madness as the shadows depend on candle.

Key-words: Ibsen; female; modern drama.

\section{UNA INSENSATEZ E DOS REALIDADES EN JOHN GABRIEL BORKMAN, DE HENRIK IBSEN}

Resumen: Henrik Ibsen es el fundador del drama moderno. Conocido por haber escrito Casa de muñecas - en la cual discute la libertad feminina cuando el personaje principal deja la casa de la família y va a afrontar el mundo externo, que não es apresentado al lector/espectador - Ibsen nos presenta, en John Gabriel Borkman, dos mujeres presas a sus realidades particulares, personales e inalterables acerca de la locura del hombre que está en el título. Este artículo desea revelar como, en este drama, diferentemente de Casa de muñecas, la dualidad feminina de la realidad depende de la locura masculina como las sombras dependen de la vela.

Palabras-clave: Ibsen; feminino; drama moderno.

1 Doutor em Letras/Literatura pela Universidade Estadual de Londrina (UEL), instituição na qual defendeu a tese sobre as representações do feminino na obra do dramaturgo norueguês Henrik Ibsen. É um dos organizadores de "De figura feminina? Os perfis da mulher na obra de Moacyr Scliar" (EDUEL, 2018) e de "Josué Guimarães nas trincheiras femininas" (EDUEL, 2019).

Revista (Entre Parênteses)

Número 9, Volume 1, 2020 - ISSN 2238-4502 


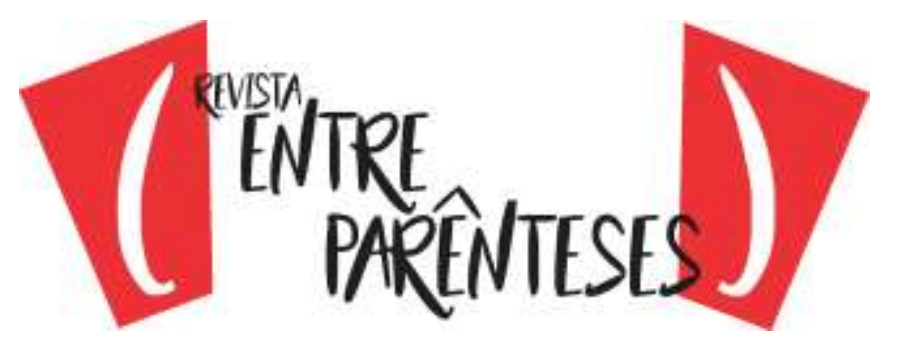

ELLA RENTHEIM, sans répondre: Etdonc, ilvitlà-haut tout seul. Absolumentisolé. (IBSEN, 2006b, p. 1578) 23.

A fábula do penúltimo drama escrito por lbsen foca a vida de um exdiretor de banco, o qual, depois de cumprir pena de cinco anos na prisão, se isola por oito anos na parte de cima da mansão que divide com a esposa - com quem não se comunica - e eventualmente com o filho, que, na maior parte do tempo, permanece na casa da tia Ella e participa de confraternizações organizadas por Madame Wilton. Depois de oito anos, Ella Rentheim, antiga paixão do banqueiro, aparece na casa, a fim de resgatar Erhart, o sobrinho, do convívio da irmã e de Madame Wilton. Aproveita os momentos no casarão, com vistas a passar a limpo os motivos que levaram Borkman a se afastar dela. Considerando Borkman o sujeito dramatúrgico em busca de seu objeto-valor (retomar sua vida social e, principalmente, sua atividade profissional no mundo financeiro), Madame Borkman, a esposa, e Ella, a cunhada, ocupam respectivamente a casa de oponente e adjuvante no modelo actancial ${ }^{4}$. Os três primeiros atos do drama transcorrem entre os pavimentos inferior e superior da mansão, e o último, entre a casa e a floresta.

Borkman enfrenta o resto de seus dias dividido entre duas mulheres, ora o fustigando pela incapacidade de retirar o nome da família da lama, ora o

\footnotetext{
${ }^{2}$ ELLA RENTHEIM, sem responder: E então, ele fica lá em cima sozinho. Absolutamente isolado.

3 São nossas as traduções francês/português dos fragmentos da obra de lbsen.

${ }^{4}$ Enfatiza Ryngaert (1996, p. 67): "O modelo actancial desenvolveu-se nos anos 70 a partir dos trabalhos de V. Propp (Morfologia do conto) e de Étienne Souriau (Les deux cent mille situations dramatiques [As duzentas mil situações dramáticas]) que tentavam constituir uma dramática da narrativa. Os semanticistas, principalmente A. J. Greimas, definiram o modelo que uma especialista como Anne Ubersfeld empenhou-se em modificar, aplicando-o ao campo teatral". O modelo actancial escancara as dimensões mais profundas do texto (especialmente as psicológicas e as ideológicas), por meio do esquema do preenchimento de seus seis elementos (destinador, objeto, destinatário, adjuvante, sujeito, oponente). Em resumo, um sujeito é "inspirado/motivado" (destinador) a alcançar um objeto, o qual, por sua vez, deverá ser entregue ao destinatário. Para conseguir o objeto, o sujeito contará com personagens ou elementos que o ajudem (adjuvante) ou o atrapalhem/impeçam (oponente) de chegar ao objetivo.
} 
direcionando à possibilidade de recuperar os anos de clausura. De um lado, GunhildBorkman, esposa do banqueiro; de outro, Ella Rentheim, sua cunhada.

John Gassner discorre acerca das personagens femininas criadas por Ibsen, especificando:

A Sra. Borkman, desenhada com grande firmeza, ao mesmo tempo em que odeia o marido, se dedica fanaticamente à tentativa de transformar o filho num superfinancista que tomará como sua missão reabilitar o nome Borkman. Representa o componente feminino nesta tragédia de um empresário. A peça golpeia nossas emoções com as eficazes criações de personagens adicionais: a frustrada irmã da Sra. Borkman e o patético clérigo Foldal que desejava ser escritor. Aqui, mais uma vez, Ibsen acentua a derrota de forma muito mais poderosa que a liberação; embora Erhart, o filho dos Borkman, rejeite a missão de sua mãe e parta com a Sra. Fanny Wilton, exigindo seu direito à felicidade, são os traços dolorosos da peça que causam a impressão mais profunda. $O$ sentimento de depressão está, realmente, de tal modo entranhado na obra que sobrecarrega John Gabriel Borkman com um peso quase insuportável. (GASSNER, 2003, p. 34).

Pensamos de maneira diferente das reflexões de John Gassner sobre as personagens femininas. Em primeiro lugar, não existe um "componente feminino" exclusivo. Além de Madame Borkman, a presença de sua irmã, Ella, é fundamental para o desenrolar da intriga, já que ambas interagem com as personagens essenciais: Borkman, Erhart e Fanny Wilton. Logo, Ella e Gunhild encontram-se no mesmo patamar do "componente feminino", equivocando-se Gassner, ao adjetivar Ella como "personagem adicional" e "frustrada" - considerando que, embora cobre esclarecimentos, jamais negligenciou Borkman, Erhart e Gunhild. O equívoco sobre a "personagem adicional" e "frustrada" chega ao ponto de Gassner sequer nomear Ella.

Mesmo cônscia do fantasma do marido sobre ela, Madame Borkman prende-se aos problemas insolúveis da família: 
O desenvolvimento da família nuclear moderna é um elemento absolutamente central na história do século XIX. A família burguesa é o núcleo interno na relação entre as esferas sociais íntimas e públicas. Nesse aspecto, o burguês apresenta-se como humano, puro e simples, mas existem também os conflitos e contradições sociais modernas, reveladas de uma maneira em que as relações individuais e interpessoais se apresentam com clareza. O que ideologicamente devia ser um idílio de felicidade, torna-se um terreno de conflitos e crises. Este é um tema na grande tradição romanesca europeia, e permanece absolutamente central nos dramas em que Ibsen trata da relação entre amor e matrimônio, impulso e razão, pais e filhos. (RONNING, 2008, p. 37-38).

Conforme destaca Ronning, o "idílio de felicidade" torna-se "terreno de conflitos e crises", no qual Madame Borkman se mantém na relação masoquista. Institui-se um contraponto entre Madame Borkman e Ella. Enquanto a esposa do banqueiro se conserva refém de seus medos dentro de casa, Ella constrói sua sólida vida financeira fora de casa: Madame Borkman permaneceu em casa, impingindo sofrimento ao marido e martirizando-se pelos rumos de sua vida; Ella saiu de casa, constituiu patrimônio, com o qual sustenta seus familiares e com o qual pretende convencer o sobrinho a abandonar a mãe e sua nova amiga, Madame Wilton, e voltar a morar com ela.

O sair de casa associado à busca de autonomia é, pois, um passo para o estabelecimento de novas relações que possibilitam a mulher a questionar, tanto ideológica quanto estruturalmente o modelo de sociedade em que vivemos. É importante ressaltar que esse movimento de "sair de casa" não é meramente uma dimensão física, de um simples deslocamento para o mundo público ou mesmo da produção. Isso, por si só, não garantiria alterações estruturais na dinâmica da divisão sexual do trabalho, ainda que possam denunciar contradições dessa dinâmica e possibilitar, em alguma medida, a relação da mulher com a vivência pública/política. Todavia, como a História nos mostra, desde a Revolução Industrial, milhares de trabalhadoras passaram a se inserir no mundo produtivo, nem por isso, deixaram de ser responsabilizadas pela reprodução social antroponômica. Tampouco passaram a ser vistas como sujeitos políticos. O "sair de casa" a que nos referimos, trata-se da desnaturalização da responsabilização da mulher pela reprodução social antroponômica, bem como da superação da aparente

Revista (Entre Parênteses)

Número 9, Volume 1, 2020 - ISSN 2238-4502 


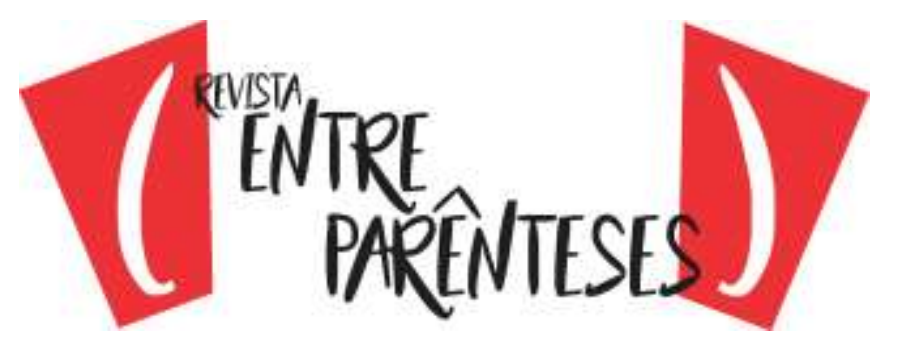

dicotomia provocada pela divisão sexual do trabalho entre o mundo da produção/público/político (considerado masculino e valorizado) e o da reprodução/privado (considerado feminino e desvalorizado). Com o "sair de casa" associado à luta por autonomia e superação da ideologia da natureza feminina, é possível provocar alterações estruturais, na medida em que há o enfrentamento à "restrição da mobilidade" (Falquet, 2012) das mulheres e à divisão sexual do trabalho. (CISNE, 2014, p. 183-184).

"Sair de casa" constitui metáfora da emancipação da mulher, a qual precisa apropriar-se de seu corpo (consequentemente, excluindo a apropriação do marido), modificar o conteúdo de seus direitos, instituir/resgatar sua individualidade, elaborar sua condição de sujeito, decidindo, entre outras questões, os requisitos para vender (ou não) sua força de trabalho (GUILLAUMIN, 2005, p. 29-39).

Durante todo o período em que ficou fora de casa, Ella não se comunicou nem com o cunhado nem com a irmã, mas continuou vinculada a ele, de modo a exigir-Ihe explicações do passado. Ella possui voz e, nos momentos adequados, aproveita as oportunidades para discutir com as outras personagens. Contudo, se existe a constatação de um grupo feminino e um masculino, tanto Ella quanto Madame Borkman (grupo feminino) se mostram oprimidas pelo masculino, uma vez que ambas, nos quatro atos, constroem seus diálogos em torno de Borkman e de seu filho, Erhart.

Borkman e Erhart não trabalham. Ou seja, não se trata de um homem sustentando uma mulher, como em Casa de bonecas, A dama do mar, Hedda Gabler, Um inimigo do povo ou Solness, o construtor. Também não se trata de responsabilidade feminina, como na atuação de Gina à frente do ateliê de fotografia, em $O$ pato selvagem. Ella trava disputas com a irmã pela posse de Borkman e com Madame Borkman e Madame Wilton, pela de Erhart. Os diálogos evidenciam cobranças, acusações, ameaças, gritos, histerias e vinganças.

O drama inicia-se com o diálogo entre a empregada Malene e Madame Borkman, a respeito de uma visitante: Ella aparece na mansão, para compartilhar a notícia de doença grave. 


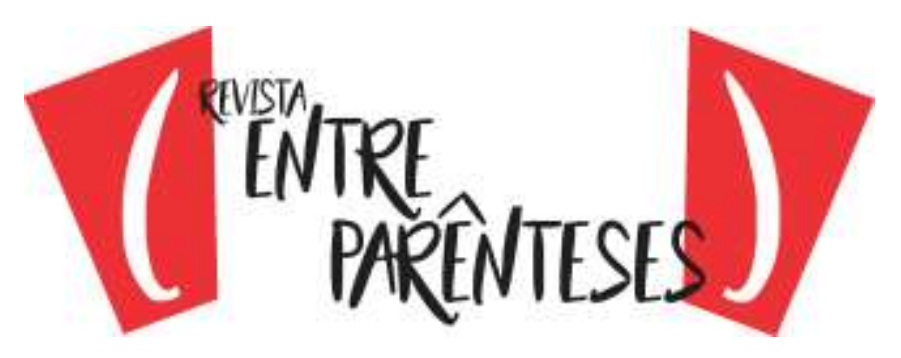

As rubricas do primeiro ato (IBSEN, 2006b, p. 1569) apontam a chegada da neve. $O$ frio e o calor são termômetros, respectivamente, de Gunhild e Ella. Algumas paixões (semióticas ${ }^{5}$ ) contrastam o ethos das irmãs. Ella procura instaurar o perdão, a compaixão e o amor, sem se importar predominantemente com a opinião pública. Já Madame Borkman caracteriza-se pelo ressentimento, amargura, vingança, ódio e nos esforços de limpar o sobrenome (IBSEN, 2006b, p. 1573-1574).

O tempo desfavoreceu Ella. Seus trejeitos e expressões faciais denunciam os sofrimentos (IBSEN, 2006b, p. 1570). Quando se encontra com Borkman, percebem-se as atribulações pelas quais passou:

ELLA RENTHEIM: Tu me reconnais?

BORKMAN: Oui, je commence à...

ELLA RENTHEIM: Les annéesm'ontrudementeéprouvée, me voicidansmonautomne, Borkman. Tu netrouvespas?

BORKMAN, se forçant. Tu as unpeuchangé. Commeça, à première vue...

ELLA RENTHEIM: Je n'ai plusmesbouclesnoiressurlanuque à présent. Ellesqu'autrefois tu aimaistantenroulerautour de tesdoigts.

BORKMAN, vite: Exact! Je le vois, Ella.Tu as changé de coiffure. (IBSEN, 2006b, p. 1603) ${ }^{6}$.

Os diálogos a respeito de frio e calor expõem carga metafórica: o frio corresponderá ao comportamento de Madame Borkman (contrária à felicidade do

\footnotetext{
${ }^{5}$ Mello (2005, p.49) assinala: "Paixões são 'estados de alma' e a literatura sobre o assunto mostra que um 'estado de coisas' leva a um 'estado de alma'. Assim, se a Semiótica estuda a busca do sujeito por objetos-valores, pode-se dizer que os 'estados de alma' aparecem porque esses sujeitos, tentando entrar com conjunção com seus objetos valores, criam 'conflitos', 'polêmicas' entre si ou, então, estabelecem entre si 'situações de cumplicidade', 'de benevolência'. As paixões podem ser definidas como modalizações do ser dos sujeitos de estados narrativos, que, no nível discursivo, aparecem concretizadas por lexemas". Neste artigo, aplicamos a Semiótica, com a finalidade de identificar quais paixões configuram as personagens na busca de seus objetos-valores.

${ }^{6}$ ELLA RENTHEIM: Me reconhece?

BORKMAN: Sim, eu começo a...

ELLA RENTHEIM: Os anos foram rudemente duros comigo, eis-me no meu outono, Borkman. Não acha?

BORKMAN, se esforçando: Você mudou um pouco. Assim, à primeira vista...

ELLA RENTHEIM: Já não tenho meus cachos pretos na nuca. Os cachos que outrora gostava tanto de enrolar nos seus dedos.

BORKMAN, rápido: Exato! Percebo, Ella. Mudou o penteado.

Revista (Entre Parênteses)

Número 9, Volume 1, 2020 - ISSN 2238-4502
} 


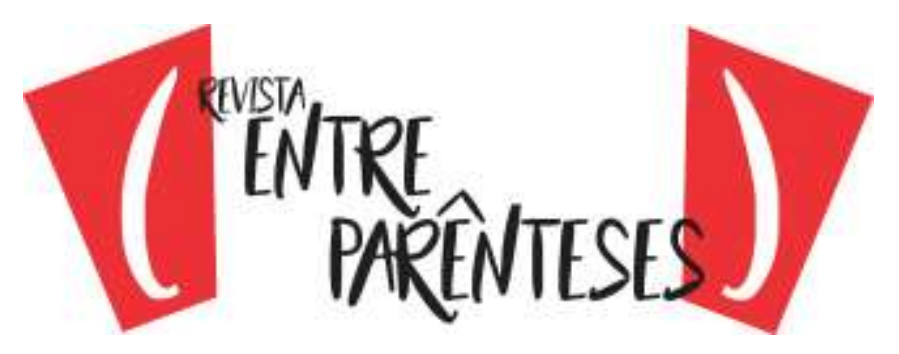

filho e à do marido) e o calor ao de Ella (favorável a Borkman e a Erhart). Borkman subjuga-se ao mundo híbrido, cheio de nuances complexas. A complexidade se exacerba, quando ilusão e realidade se misturam e, nesse quesito, Madame Borkman aponta a confusão do esposo:

\begin{abstract}
MADAME BORKMAN, avecmépris: Oui, nousdevionstoujours "representer" à ce que l'ondisait. Etpourrepresenter, ilreprésentaitcommeilfaut! II menaitequipage à quatre... comos'ilavaitétéunroi. Ilfaisaitensorte que les gens le saluent et l'acclamentcomme un roi. (Riant.) Et on l'appelait par son prénom... d'un bout à l'autre du pays... exactmentcommes'ilétait le roienpersonne. "John Gabriel", "John Gabriel". Tout le monde. (IBSEN, 2006b, p. 1573) ${ }^{7}$.
\end{abstract}

A entrada em um castelo pode levar o indivíduo ao império de ilusões e alucinações. O tratamento irônico do reino remete à sua desilusão sobre os propósitos que ele jamais alcançará. Quando, no segundo ato, Borkman conversa com Frida, filha de Foldal, elogiando sua habilidade ao piano, relembra sua infância permeada da música dos metais retirados das minas:

BORKMAN: Je suis fils de mineur, vouslesavez. Ou peutêtrenelesavez-vouspas?

FRIDA: Non, monsieur Borkman.

BORKMAN: Fils de mineur. Et mon pèrem'emmenaitparfoisdans le mines... Là, enbas, lemétal chante. (IBSEN, 2006b, p.1592) ${ }^{8}$.

Baixo/cima, por baixo/por cima, embaixo/em cima são sinônimos, no tratamento de quem se enquadra no alto (burguesia) e de quem deve permanecer no chão (proletariado). Apesar de visivelmente encontrar dificuldade na transição

\footnotetext{
${ }^{7}$ MADAME BORKMAN, com menosprezo: Sim, nós devíamos sempre "representar" o que se dizia. E para representar, ele representava como se deve! Ele conduzia a tripulação... como se ele tivesse sido um rei! Ele fazia com que as pessoas o saudassem e o aclamassem como um rei. (rindo). E o chamávamos por seu primeiro nome... de um extremo a outro do país... exatamente como se ele fosse um rei em pessoa. "John Gabriel", "John Gabriel". Todo mundo.

8 BORKMAN: Sou filho de mineiro, você sabe. Ou talvez não saiba?

FRIDA: Não, senhor Borkman.

BORKMAN: Filho de mineiro. E meu pai me levava algumas vezes às minas... Lá embaixo, o metal canta.
}

Revista (Entre Parênteses)

Número 9, Volume 1, 2020 - ISSN 2238-4502 


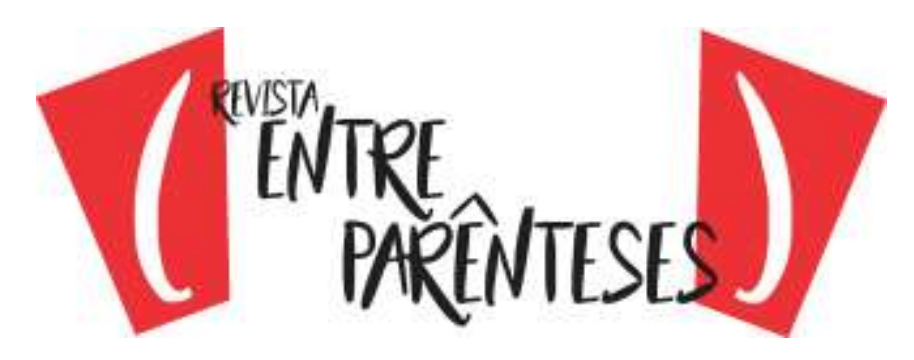

entre proletariado e burguesia, Borkman se sente inserido nesta, desprezando os integrantes daquele:

BORKMAN, sombre, regardantdevantlui tout entambourinant sur la table: Eh oui, voilà l'affaire. C'estune malediction que nous autres, nous seuls, les élus, avons à supporter. La masse et la plèbe... tous les medíocres... ils ne nous comprennent pas, Vilhelm. (IBSEN, 2006b, p. 1595) ${ }^{9}$.

Uma metáfora também encerra a vida de Borkman, quando, no último ato, acompanhada da empregada, sua esposa o encontra com a irmã, numa floresta. A informação de que uma mão estranha teria esmagado seu coração, provocando-lhe a morte, preocupa, mas não espanta Madame Borkman. Ela aguardava por este momento: "MADAME BORKMAN, refusant: Non, non, non. (Baissantlavoix.) C'étaitlefils d'unmineur... lui, ledirecteur de banque. II n'a paspusupporterl'airfrais." (IBSEN, 2006b, p. 1641) ${ }^{10}$.

O filho de mineiro deveria esconder-se com outros mineiros, embaixo do solo. Contudo, esse filho de mineiro ousou abandonar o ventre da terra e sair da escuridão, para andar sobre ela e desfilar à luz. Entre trevas e luz, escondido e exposto, proletário e burguês, há um caminho híbrido a ser seguido, mas, como salienta Madame Borkman, o filho do mineiro não tinha condições de enfrentá-lo por muito tempo, afinal, "ele não suporta o ar fresco" e as consequências que o gelo poderia acarretar, como, por exemplo, a diminuição do ritmo cardíaco.

Se pensarmos no modelo actancial, o objeto-valor de Borkman se constituiria pelo desejo de voltar à luz, ao trabalho, à vida social. Madame Borkman ocuparia a casa do oponente, articulando argumentos contrários ao desejo do sujeito. Ella encarregar-se-ia da casa do adjuvante, estimulando o alcance desse

\footnotetext{
9 BORKMAN, sombrio, olhando em direção a ele e tamborilando na mesa: Sim, eis a questão. É uma maldição que, apenas nós, os eleitos, temos de suportar. A massa e a plebe... todos os medíocres... Eles não nos compreendem, Vilhelm.

10 MADAME BORKMAN, recusando: Não, não, não. (baixando a voz.) Era um filho de mineiro... ele, o diretor do banco. Ele não pode suportar o ar fresco.
}

Revista (Entre Parênteses)

Número 9, Volume 1, 2020 - ISSN 2238-4502 


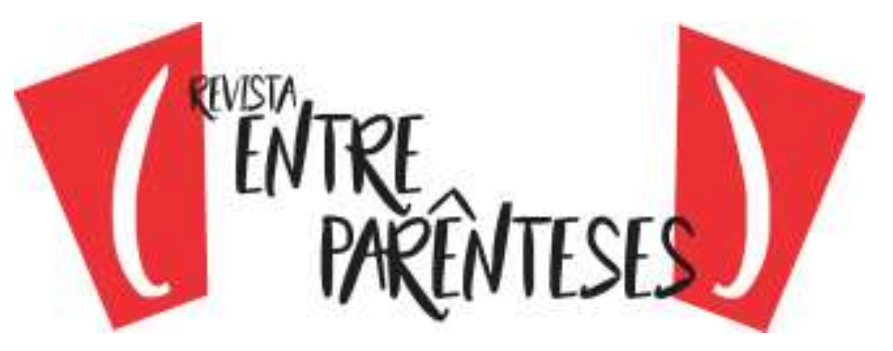

objetivo. Importante ressaltar que, embora incentive Borkman a reassumir sua vida, Ella não se esquece dos erros cometidos por ele, os quais a abalaram sentimentalmente, pressuposto de sua doença (IBSEN, 2006b, p.1573). A obra de Ibsen concentra-se na dualidade, incluindo-se a feminina, que, de alguma maneira, se aproximaria do binarismo do qual tentam se afastar atualmente os estudos feministas. Qualquer movimentação do sujeito em busca de seu objeto-valor ativa os motores do oponente e do adjuvante.

Durante todo o drama, Madame Borkman ataca o marido, desdenha sua origem humilde, responsabiliza-o pela ruína da família, culpa-o pela infelicidade dela e do filho, recusa-se a conceder-Ihe perdão. Ella, por sua vez, ocupa a função de adjuvante, incentiva o banqueiro a voltar à vida social e profissional e quebrar seu isolamento (IBSEN, 2006b, p.1620), estimulando a irmã a dar-lhe o perdão (IBSEN, 2006b, p.1573, p. 1577-1578).

Assim ocorre igualmente com Erhart. Ella e Madame Borkmam o disputam antes e depois da informação de que desejam que escolha uma das duas. A tia apega-se à circunstância da proximidade da morte e de destinar-lhe integralmente sua herança. Madame Borkman ressalta os laços maternos, lembrando-o da missão de resgatar o nome da família do caos no qual o pai o meteu. Nesse momento, ambas trocam de casa, no modelo actancial, ora funcionando como sujeito, ora como oponente. Erhart é o objeto-valor delas. Para conquistá-lo, Ella ocupa o lugar de sujeito dramatúrgico, arregimentando os fatos relacionados à sua doença e, na condição de oponente ao sujeito, sobressai-se em relação a Madame Borkman, recorrendo aos seus argumentos, já expostos. Esses mesmos argumentos da mãe o inserirão na casa de sujeito dramatúrgico, contra quem se voltará o oponente, encarnado na figura de Ella.

Madame Borkman sente-se atraiçoada pelo fato de o marido arruiná-la (IBSEN, 2006b, p. 1571-1572). Entretanto, há um plano: um projeto de reparação da honra, a cargo de seu filho: 


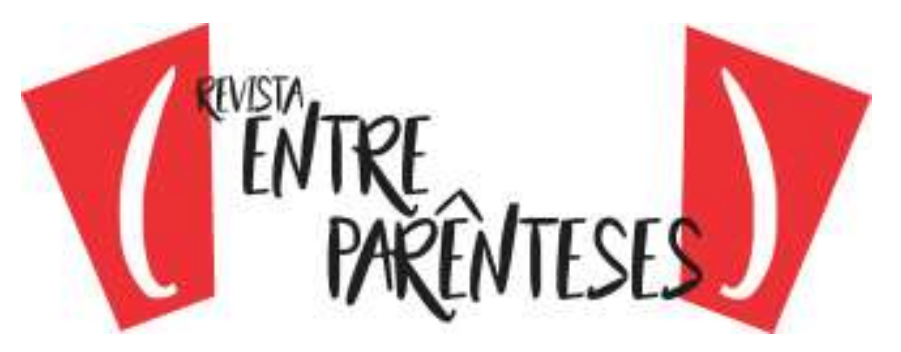

ELLA RENTHEIM, tendue: Réparation? Qu'est-ce que tu veuxdire par lá?

MADAME BORKMAN: Réparation pour mon nom, pour mon honneur, pour mon bien-être. Réparation pour tout ma destinéegâchée, je veux dire! J'aiquelq'unenréserve, moi, tusais... Quelq'unquivalaver tout ce que... ce que ledirecteur de banque a sali. (IBSEN, 2006b, p. 1573) ${ }^{11}$.

A discussão entre Madame Borkman e Ella se estende, a ponto de a tia indagar se a proposta de resgate do status da família recebera a anuência de quem, em tese, deveria assumir a empreitada:

MADAME BORKMAN, la regardant de haut, gravement: Erhartdoitavant tout veiller à brillersi haut etsi fort que personnedansce pays n'entrevoi plus l'ombre que son père a jetée sur moi... et sur mons fils.

ELLA RENTHEIM, la scrutant: Dis-moi, Gunhild ... estcelál'exigencequ'Erhartlui-même a fixée à sa vie?

MADAME BORKMAN, tressaillant: Oui, ilfautl'ésperer!

ELLA RENTHEIM: ...ou bien n'est-cepasplutôt une exigence que tu as fixéepourlui?

MADAME BORKMAN, sèchement: Erhartetmoiavonstoujours les mêmesexigencesenvers nous-mêmes. (IBSEN, 2006b, p. 1575) ${ }^{12}$.

O afoito objetivo de Madame Borkman a impulsiona em direção ao filho e atiça sua revolta contra o marido. Ella ainda ensaia um paliativo, a fim de restabelecer a comunicação entre marido e mulher, mas a irmã resiste à proposta:

\footnotetext{
${ }^{11}$ ELLA RENTHEIM, tensa: Reparação? O que você quer dizer com isso?

MADAME BORKMAN: Reparação por meu nome, por minha honra, por meu bem-estar. Reparação por todo o meu destino destruído, é o que eu quero dizer. Eu tenho esperança em alguém, eu, você sabe... Alguém que vai limpar tudo o que... o que o diretor do banco sujou.

12 MANDAME BORKMAN, olhando-a de cima, seriamente: Erhart deve dedicar-se a brilhar tão alto e tão forte que ninguém neste país possa entrever a sombra que seu pai lançou sobre mim... e sobre meu filho.

ELLA RENTHEIM, observando-a atentamente: Diga-me, Gunhild... Essa pretensão é a que o próprio Erhart fixou para sua vida?

MADAME BORKMAN, estremecendo: Sim, é o que se espera.

ELLA RENTHEIM:... ou é uma pretensão que você estabeleceu para ele?

MADAME BORKMAN, secamente: Erhart e eu temos sempre as mesmas pretensões para nós mesmos.
}

Revista (Entre Parênteses)

Número 9, Volume 1, 2020 - ISSN 2238-4502 


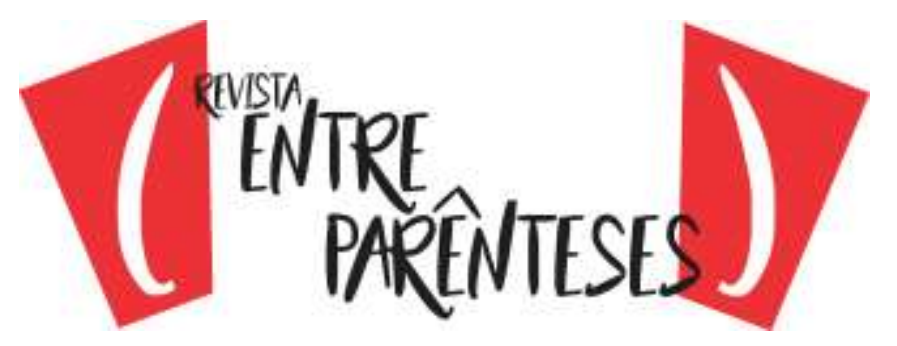

ELLA RENTHEIM: Mais toi, tu nepourraispasfairele premier pas?

MADAME BORKMAN, s'emportant: Moi! Après tout cedontils'estrenducoupableenversmoi!... Non, merci. Plutôtlaisser le loup continuer là haut.

ELLA RENTHEIM: J'ai trop chaudici. Tu me permettrasbien d'enlevermonmanteau. (IBSEN, 2006b, p. 1577) ${ }^{13}$.

Aqui duas metáforas voltam a aparecer: calor e andar de cima. Diante do comportamento intransigente de Madame Borkman, Ella volta a se livrar de seu casaco. Seu calor contrasta com o frio da irmã, inflexível ao recusar a comunicação com o marido. Por sua vez, Borkman vive num mundo de ilusão. Já que ele caiu do alto de seu cargo de chefia, pelo desejo implacável de poder, agora, o "alto" é sinônimo de isolamento. Algumas vezes, Borkman pensa em sair de casa, mas dá meia-volta. Quase sempre espera a visita de Foldal ou de sua filha pianista, Frida (IBSEN, 2006b, p. 1577-1578).

Os comportamentos intolerantes e intoleráveis de Madame Borkman são alguns dos motivos que levam Ella a se mudar para a mansão. $O$ fim do segundo ato abriga o bate-boca entre as irmãs, ao tratarem de quem ficará com Erhart.

Com o intuito de conseguir um aliado, Ella sobe ao quarto de Borkman e sugere assumir a maternidade de Erhart. A mudança de filiação asseguraria o direito à sua herança. Ainda digerindo a proposta, Borkman e a cunhada surpreendem-se com a invasão de Madame Borkman. Para Ella, o amor de Borkman e o amor materno por Erhart emparelham-se em relevância (IBSEN, 2006b, p. 1614-1615). Diante da disputa, com quem ele ficaria? Entre a mãe e a tia, ele opta pela terceira via:

ELLA RENTHEIM: Oui, mourante. Veux-tu demeurer chez moi jusqu'audernierinstant? T'attachercomplètement à moi? Être pour moicommemonpropre enfant...

${ }^{13}$ ELLA RENTHEIM: Mas você não poderia dar o primeiro passo?

MADAME BORKMAN, sobrepondo-se: Eu, depois de tudo, ele é responsável contra mim!... Não, obrigada. Talvez deixe o lobo continuar lá em cima.

ELLA RENTHEIM: Está muito quente aqui. Permita-me tirar meu casaco.

Revista (Entre Parênteses)

Número 9, Volume 1, 2020 - ISSN 2238-4502 
MADAME BORKMAN, l'interrompant:... et trahir ta mère et peut-être ta mission dans la vie aussi? Tu le veux, Erhart?

ELLA RENTHEIM: Je suiscondamné à m'enaller. Reponds-moi, Erhart.

ERHART, chaleureusement, ému: Tante Ella... Tu as été si bonnepour moi. Chez toi, il m'a étépermis de grandirdansunsentimentinsouciant bonheurcommejecroisqu'ildoitexisterdanstoutevie d'enfant... MADAME BORKMAN: Erhart, Erhart!

ELLA RENTHEIM: Oh! Quellebénédiction que tupuissesvoir encore les choses ainsi!

ERHART: ... mais je ne peux pas me sacrifier à toimaintenant. IIm'est impossible d'être exclusivement un fils pour toi...

MADAME BORKMAN, triomphante: Ah! Jelesavaisbien! Tu nel'auraspas! Tu nel'auraspas, Ella!

ELLA RENTHEIM, tristement. Jelevois. Tu l'asreconquis.

MADAME BORKMAN: Oui, oui... II est à moi etilrestera à moi! Erhart... n'est-pas... nous deux, nous avons encore un bout de chemin à faire ensemble.

ERHART, luttantcontrelui-même: Mère... autantte le dire carrément... MADAME BORKMAN, tendue: Eh bien?

ERHART: Ce ne seráprobablementqu'un petit bout de chemin que jevais faire avec toi, mère.

MADAME BORKMAN, commefrappée: Qu'est-ce que tuveux dire par lá?

ERHART, rassemblant tout son courage: Seigneur Dieu, mère... Je suis jeunequandmême! J'ail'impression que l'airrenfermé de cettepiècevafinir par m'étoufferpurementetsimplement.

MADAME BORKMAN: Ici... chez moi!

ERHART: Oui, ici, chez toi, mère! (IBSEN, 2006b, p. 1622) ${ }^{14}$.

${ }^{14}$ ELLA RENTHEIM: Sim, moribunda. Quer permanecer em minha casa até o último minuto? Ligar-se completamente a mim? Ser para mim como um filho...

MADAME BORKMAN, interrompendo: ... e trair tua mãe e talvez a missão de tua vida também? Quer, Erhart?

ELLA RENTHEIM: Estou condenada a partir. Responda-me, Erhart.

ERHART, calorosamente, emocionado: Tia Ella... Você foi tão boa para mim. Na sua casa, permitiume crescer um sentimento despreocupado de felicidade como eu creio que deva existir na vida de toda criança...

MADAME BORKMAN: Erhart, Erhart!

ELLA RENTHEIM: Que bênção que veja as coisas dessa maneira!

ERHART: ...Mas não posso me sacrificar por ti agora. É impossível ser exclusivamente um filho para ti...

MADAME BORKMAN, triunfante: Ah! Eu sabia! Você não o terá! Você não o terá, Ella!

ELLA RENTHEIM, tristemente: Percebo! Você o reconquistou.

MADAME BORKMAN: Sim, sim... ele é meu e ficará comigo! Erhart... não é... Nós dois, nós temos um bom caminho para percorrermos juntos.

ERHART, lutando contra ele mesmo: Mãe... preciso falar-Ihe francamente.

\section{Revista (Entre Parênteses)}

Número 9, Volume 1, 2020 - ISSN 2238-4502 
Quem ganha a disputa sobre Erhart é Madame Fanny Wilton: convence-o a sair da cidade e a iniciar a vida em outro lugar. A notícia pega a todos de surpresa. É noite. A neve cai. O trenó já os aguarda. Madame Borkman protagoniza escândalo, na tentativa de impedir o filho de partir, mas Ella a retém. Embora favorável ao novo amor do sobrinho, Ella não disfarça a reprovação ao estado civil de Madame Wilton: divorciada (IBSEN, 2006b, p. 1579-1580). O entrevero da despedida instiga o embate (IBSEN, 2006b, p. 1626): Madame Borkman também acusa Fanny pela dissolução de seu casamento.

A culpa da mulher pelo fracasso da relação matrimonial ou sua definição incompleta, inferior ou desqualificada, acompanha isotopicamente a construção da obra. Foldal e Borkman acusam as mulheres de complicarem a vida, de serem todas iguais e de não possuírem valor.

BORKMAN, indigné: Oh! Ces femmes! Elles nous gâchent, elles nous compliquent la vie! Ellesfaussenttoutenotredestinée... toutenotremarchetriomphale.

FOLDAL: Pas toutes, voyons!

BORKMAN: Ah bon? Nomme-m'emuneseule qui vaillequelque chose! FOLDAL: Oui, bien sur, voilà l'affaire. Les rares que jeconnaisse ne valent rien (IBSEN, 2006b, p. 1601) ${ }^{15}$.

Configura-se a mulher de valor, a que "vale algo" ou "nada vale", de acordo com o interesse dos homens. O diálogo entre Borkman e Foldal demonstra a

MADAME BORKMAN, tensa: Como?

ERHART: Provavelmente, estarei com você apenas uma pequena parte do caminho, mãe. MADAME BORKMAN, como golpeada: O que você quer dizer?

ERHART, reunindo toda sua coragem: Meu Deus, mãe... Eu sou jovem! Tenho a impressão de que o ar fechado deste lugar vai acabar me asfixiando, pura e simplesmente.

MADAME BORKMAN: Aqui... na minha casa?

ERHART: Sim, aqui, na sua casa, mãe.

15 BORKMAN, indignado: Oh! Essas mulheres! Elas nos sabotam, nos complicam a vida. Elas desfiguram todo o nosso destino...toda a nossa marcha triunfal.

FOLDAL: Não todas.

BORKMAN: Não? Diga-me uma só que valha alguma coisa.

FOLDAL: Sim, seguramente, eis a questão. As raras que eu conheço não valem nada.

Revista (Entre Parênteses)

Número 9, Volume 1, 2020 - ISSN 2238-4502 


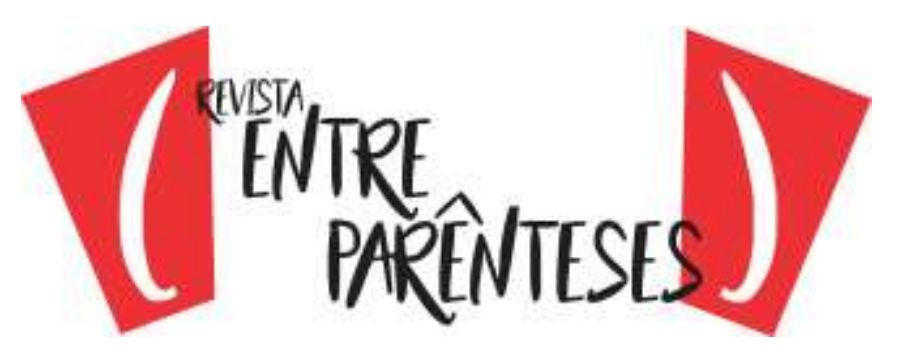

insatisfação pelas barreiras intransponíveis criadas contra ambos - um financista fracassado e um escritor incapaz - diante de um mundo transformado. Para eles, a subserviência feminina é um degrau a ser pisado rumo ao sucesso:

A ideologia dominante, patriarcal-racista-capitalista, penetra na consciência dos indivíduos devido à naturalização das relações de dominação e exploração que a alienação produz. Essa naturalização dificulta a possibilidade de se pensar e agir de forma transformadora. Com isso, muitos indivíduos não percebem essas relações como tais [de dominação e exploração] ou, quando percebem, não acham possível alterá-las. É essa alienação que faz com que mulheres naturalizem e reproduzam sua condição de subalternidade e subserviência como algo inato ou mesmo biológico. (CISNE, 2014, p. 95).

Interrompe-se a reprodução da condição de subalternidade e subserviência, quando o subalterno ou subserviente encontra condições de falar sem intermediários, apresentando suas próprias limitações e denunciando os incômodos ou abusos cometidos contra ele. Se, segundo Borkman, todas as mulheres são iguais e sem valor, elas podem se substituir umas por outras, sem prejuízo ou problema: "BORKMAN: Mais ilfaut te rappeler que je suis unhomme. Entant que femme, tu as étépour moi cequ'il y avait de plusprécieuxau monde. Maisquandil le fautabsolument, une femme peuttoujoursêtreremplacée par uneautre..."16 (IBSEN, 2006b, p. 1608-1609). A concepção da mulher como objeto a ser substituído de acordo com seus desejos ou necessidades não está inteiramente equivocada:

No contexto do itinerário obliterado do sujeito subalterno, o caminho da diferença sexual é duplamente obliterado. A questão não é a da participação feminina na insurgência ou das regras básicas da divisão sexual do trabalho, pois, em ambos os casos, há "evidência". É mais uma questão de que, apesar de ambos serem objetos da historiografia colonialista e sujeitos da insurgência, a construção

\footnotetext{
${ }^{16}$ BORKMAN: Mas é necessário lembrar-Ihe de que sou um homem. Como mulher, você poderia ser para mim o que havia de mais precioso no mundo. Mas, quando absolutamente necessário, uma mulher pode ser sempre substituída por uma outra...
} 


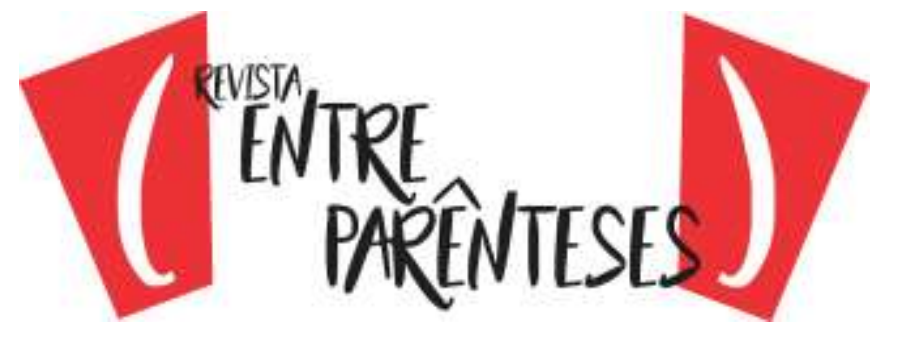

ideológica de gênero mantém a dominação masculina. Se, no contexto da produção colonial, o sujeito subalterno não tem história e não pode falar, 0 sujeito subalterno feminino está ainda mais profundamente na obscuridade. (SPIVAK, 2010, p. 66-67).

Se facilitássemos 0 entendimento do leigo ao fragmento acima, poderíamos "traduzi-lo" da seguinte maneira: a mulher está abaixo do nada e além de coisa nenhuma. Provavelmente por conceber a imagem da mulher como objeto, Borkman atribuirá a Ella a culpa de sua derrocada, já que a cunhada - "não tem história e não pode falar" e "está ainda mais profundamente na obscuridade", insignificante e irrelevante - é a causa (IBSEN, 2006b, p. 1609). Ella aponta Borkman como único destruidor de sua alegria e de sua vida (IBSEN, 2006b, p. 1610). A fragilidade destrutiva da alegria e da vida de Ella cria um espaço entre masculino e feminino. Configurando o homem, Borkman (IBSEN, 2006b, p. 1606) o define como mescla de dúvida e crença, portanto, mais incerteza e tempestade do que convicção e terra firme. Dele não discorda Madame Wilton (IBSEN, 2006a, p. 1629), ao ratificar a inconstância masculina proveniente da mesma fonte da feminina.

Sem consciência de sua condição subalterna, as personagens femininas desconhecem as peculiaridades entre sujeito (de direitos) e objeto. São mulheres que, apesar de, em algum momento, ocuparem a casa de sujeito dramatúrgico, se distanciam da possibilidade de se tornarem sujeitos de direito. Citando NicoleClaude Mathieu, Jules Falquet esclarece (2011, p. 14) que a situação de subserviência feminina ocorreu, não em decorrência de consentir, mas de ceder aos mecanismos de opressão masculina.

Inaugura-se o penúltimo ato com a descida de Borkman ao espaço da esposa, tentando explicar-se com a ajuda da cunhada. Entre subida e descida, a alternância entre luz e sombra. Fora, neve, escuro; dentro, frio/calor, luz. Quando Gina e Hjalmar ( $O$ pato selvagem) vão abordar a verdade, a esposa, a pedido do marido, acende a luz para clarear os fatos. Em nosso caso, a rubrica (IBSEN, 2006b, 


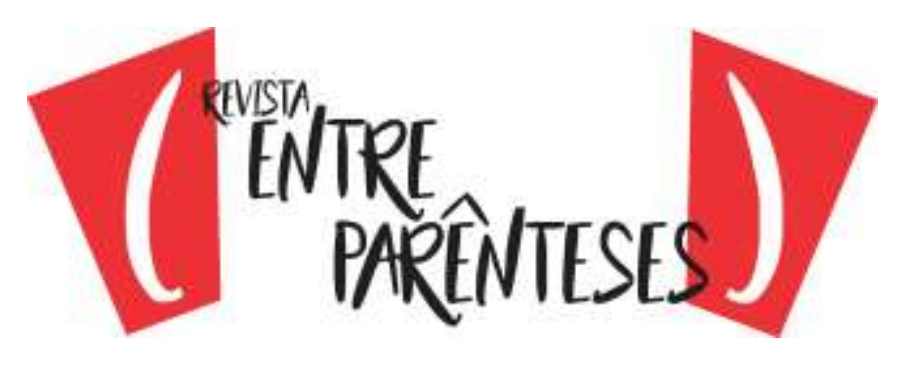

p. 1615) indica a lâmpada iluminando o sofá, aguardando a clareza que não é requerida lá fora.

O fim do terceiro ato coincide com Borkman do lado de fora da casa. Em pouco menos de vinte e quatro horas, rompeu o silêncio de oito anos com a esposa e os limites físicos de seu claustro. Ella tentou impedir sua saída; a esposa pouco se importou. Borkman convida Ella para caminhar pela montanha, retomar o velho banco, no qual tantas vezes gargalharam e traçaram planos. Sentados, o passado e o presente se misturam. Antes, Ella indagara: "Mais porquoiavons-nousbesoin de monter si haut?"17 (IBSEN, 2006b, p. 1637). Certamente, não seria pela ambição de conquistar o poder e destruir-se com ele. Talvez um momento de o filho do mineiro, escondido embaixo do solo e na escuridão, subir à superfície e alcançar a luz.

Diferentemente de Madame Wilton - objeto de discussão entre as outras personagens ou aparecendo na condição de nova parceira de Erhart -, Ella e Madame Borkman não quebram estereótipos. São retratos de mães - biológicas ou afetivas - em disputa do filho, do casamento (Madame Borkman) ou da conservação da moral e bons costumes (Ella) ou da família (ambas). Apesar de apaixonada pelo marido da irmã - ele, nem tanto assim - o amor de Ella fundamenta-se mais em virtude do que em erotismo.

Tanto Ella quanto Gunhild se mantêm refratárias ao divórcio, condenando Fanny Wilton pela iniciativa, e ratificam os conceitos cristalizados das funções de homem e mulher. Embora as duas irmãs briguem incansavelmente pelo marido/cunhado e pelo filho/sobrinho, ambas concordam - não por uma estratégia de atingir objetivo de conquistar Borkman e Erhart, mas por características pessoais - na condenação do fim dos laços matrimoniais. A elas falta a percepção de que bem ou mal, o texto não nos fornece pistas contundentes - Madame Wilton se libertou da prisão do casamento, que transforma a mulher em objeto do homem e a coage à cessão gratuita de sua força de trabalho (GUILLAUMIN, 2005, p. 20),

\footnotetext{
${ }^{17}$ Mas por que nós precisamos subir tão alto?

Revista (Entre Parênteses)

Número 9, Volume 1, 2020 - ISSN 2238-4502
} 
apropriando-se de seu tempo, sexo e produtos do corpo e impondo-lhe obrigações de cuidar dos membros da família (GUILLAUMIN, 2005, p. 26).

Ella e Gunhild disputam os homens a que estão ligadas (Borkman e Erhart), confirmando expressamente a dependência em relação a ambos (IBSEN, 2006b, p. 1641). Em uma intriga de homem em frangalhos, Ella e Gunhild funcionam como adjuvante e oponente de um sujeito estraçalhado, cuja morte ocorre em devaneio de passagem entre o passado que não se encerra e um presente que não liberta.

Um dos pontos altos da dramaturgia de Ibsen reside na sua percepção sobre as relações entre homens e mulheres, na configuração tanto da sociedade quanto da família burguesas. De maneira geral, percebe-se, no corpus examinado, homens destoantes do modelo patriarcal vigente e mulheres - seja na condição de protagonistas, seja na de coadjuvantes, seja na de sujeito histórico ou sujeito dramatúrgico - aptas a buscar uma saída diante dos problemas do percurso. Dessa forma, Borkman é representante do mundo enfraquecido, cujos abalos interiores resultam na morte de suas personagens, incapazes da libertação psicológica.

Quando Gassner (2003, p. 32-33) compara Solness (1960c) e Borkman constata-se que Ibsen se revelou

[...] mais bem-sucedido com John Gabriel Borkman, escrita em 1896, onde o idoso dramaturgo demonstrava uma intensidade bastante maior que aquela que vinha exibindo já há alguns anos. Retornou nesta peça ao tema da traição do amor ou do sacrifício do amor em proveito de vantagens materiais, que já abordara n'Os pilares da sociedade. Borkman renunciou ao seu amor por Ella Rentheim a fim de abrir caminho no mundo das finanças quando o homem capaz de assegurar seu sucesso, e que acontecia estar também apaixonado pela mesma moça, insistiu no sacrifício. Ao invés de Ella, Borkman desposou sua fria e indiferente irmã e, não sentindo nenhum amor por esta, permitiu que sua paixão pelo poder, que já era egrégia, o intoxicasse completamente. Esta o conduziu às vertiginosas alturas da especulação financeira até chegar o momento da queda; arruinou centenas de investidores, pequenos e grandes, e ele próprio foi à bancarrota com os demais. Emergiu de cinco anos de prisão totalmente arrasado e àqueles acrescentou oito anos de reclusão

Revista (Entre Parênteses)

Número 9, Volume 1, 2020 - ISSN 2238-4502 


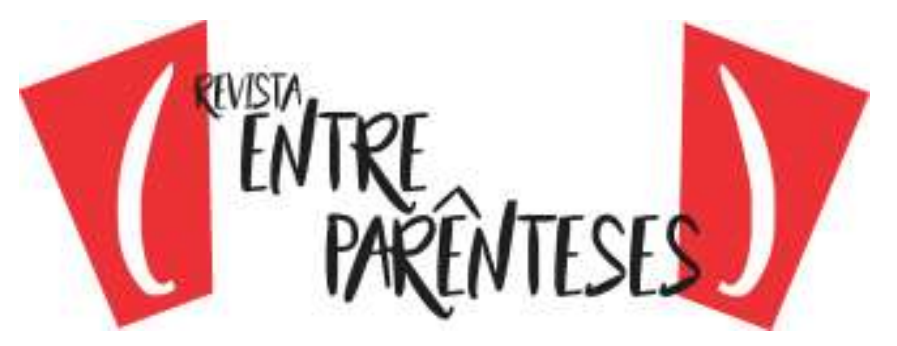

voluntária em seu quarto. Apenas quando é tarde demais encontra a liberdade e a coragem por intermédio de Ella Rentheim; ao deixar sua casa, "o frio" o mata. A morte lhe é trazida pelo mesmo elemento que já o matara espiritualmente há muito tempo atrás.

Borkman pretendia, reunindo o dinheiro dos clientes do banco, produzir felicidade. Ele não chega a roubar o numerário ou a se enriquecer ilicitamente, com eventuais juros e demais rendimentos ou benefícios, contudo, a descoberta de seu esquema o conduz à cadeia, fomentando o repúdio social que já assombrara Helmer (Casa de bonecas) ou arruinara Ekdal (O pato selvagem). Antes do desfalque e depois de cumprir sua pena, Borkman enfrenta uma avalanche de sentimentos e de reflexões em torno não apenas de suas ações burocráticas e financeiras, mas também do caminho escolhido para atingir seus objetivos. Entre eles, recusar o amor de Ella, para se casar com quem, em tese, deveria ocupar o lugar de cunhada:

A complexa trama de novo centra-se na escolha ética equivocada de Borkman quando abriu mão de seu amor por Ella e, posteriormente, da vida durante 16 anos, na espera de uma redenção que nunca veio. Em consequência do reencontro com Ella, resolve sair do isolamento e enfrentar a vida de novo, mas agora é tarde demais e, numa dramática cena final, ele morre junto com Ella em um banco perto de sua casa. A figura de Borkman parece inspirada pelas ideias nietzscheanas do super-homem e da vontade de poder. Seu idealismo fascina pela certeza expressa de suas verdades e suas consequências sinistras para todos a seu redor. De novo lbsen afunda nas contradições do idealismo ao confrontar os ideais e os idealistas ceticamente em uma crítica ao otimismo desenvolvimentista da modernidade. A força da natureza emerge no final de uma grande tempestade de neve, um símbolo implacável da fragilidade dos sonhos humanos. (SCHOLLHAMMER, 2008b, p. 8586).

A "fragilidade dos sonhos humanos" aparentemente acompanha a construção da obra do dramaturgo, ao observar que, muitas vezes, aprofunda qualidades e defeitos psicológicos das personagens, tomando emprestado o cerne de ethos anteriores. Jacques De Decker (2006, p. 177-178) acredita na concepção de Borkman a partir das incompletudes e convicções do Cônsul Bernick, 


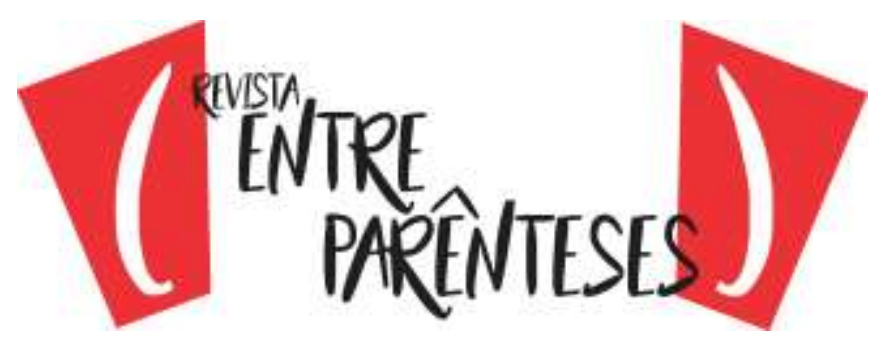

protagonista de Os pilares da sociedade, capitalista cujo plano de negócios consiste em arrasar seus clientes e lucrar com a desgraça deles.

Contudo, a diferença entre Bernick e Borkman sobressai na concepção das personagens: Bernick golpeia terceiros, com o objetivo de enriquecer, Borkman almeja o desenvolvimento econômico, pressuposto da felicidade. No entanto, ambos, ajudados por mulheres, conseguem recompor suas vidas. Bernick, assumindo publicamente seus erros, recebe o perdão. Borkman, sem possibilidades de se defender adequadamente, continua, assim como Ekdal, rejeitado pela sociedade.

No final do ano de 1896 chega ao público a penúltima peça de lbsen, John Gabriel Borkman, a história de um homem velho e vencido pela vida que, no fim, foi mais forte que suas fantasias. Borkman é um dos maiores personagens masculinos do autor. Tem os sonhos mais grandiosos e, na mesma proporção e intensidade, é despojado de tudo. Queria ser rico e poderoso o suficiente para "tornar os homens mais felizes", mas a sua obstinação acaba por destruí-lo. Como todas as outras peças de lbsen, os personagens estão presos ao passado. Há sempre um momento, distante no tempo, em que alguém foi duro, praticou uma violência consigo mesmo ou outrem. Em suas obras, lbsen dá uma segunda chance a estas pessoas se reabilitarem. Às vezes conseguem, como em Os pilares da sociedade, muitas outras vezes não, como em John Gabriel Borkman e tantos outros que soçobraram em meio a seus sonhos desumanizados. (MENEZES, 2006, p. 52).

A "fragilidade dos sonhos humanos" ou dos "sonhos desumanizados" induzem Borkman à desilusão, à frustração e ao sofrimento. Bernick e Borkman voltam a se encontrar, no muro das lamentações. São personagens masculinas angustiadas pela vontade do exercício pleno de seus desejos, mas se fixam aquém das possibilidades reais. Os sonhos são grandiosos, porém, ainda maiores são os obstáculos da realidade objetiva, cujo impacto apresenta resultados devastadores. Como empreendedores do mundo capitalista efervescente, Bernick e Borkman 


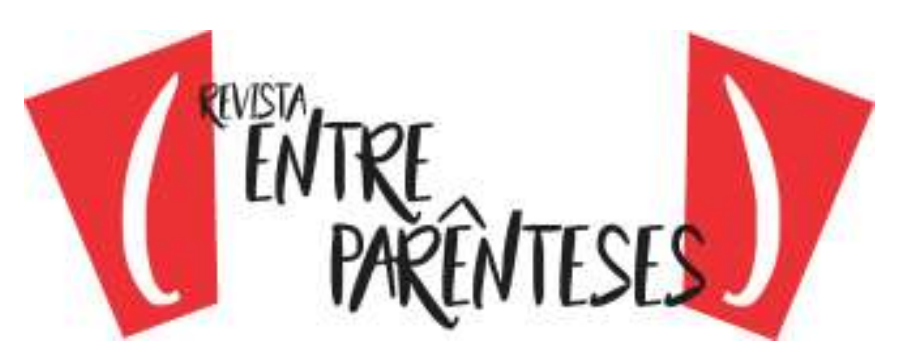

estudam de modo equivocado a conjectura, apostando mais nos lucros e nos grandes resultados do que nos prejuízos e nos seus terremotos abruptos:

O mundo de Bernick era feito de florestas, minas e quedas-d'água; o de Borkman, de espíritos, fantasmas e amor. O capitalismo é desmaterializado: os "depósitos de minérios" se tornaram reino, sopro, vida, morte, esplendor, glória... A prosa é invadida por figuras de linguagem: uma saudação de espíritos cativos, veios de metal sedutores, tesouro naufragando no abismo, clamando pela vida... As metáforas (esta é a sequência metafórica mais longa do ciclo inteiro) já não interpretam o mundo: obliteram-no e em seguida o refazem, à maneira do incêndio noturno que limpa o caminho para o construtor Solness. Destruição criativa: a área cinzenta se torna sedutora. Típico do empreendedor, afirma Sombart, é "o dom do poeta - o dom metafórico - de evocar na mente de seu público imagens arrebatadoras de domínios do ouro"; "ele mesmo, com toda a intensidade passional de que é capaz, sonha o sonho do resultado bem-sucedido de seu empreendimento".

[...]

Visionário, despótico, destrutivo, autodestrutivo: assim é o empreendedor de lbsen. (MORETTI, 2014, p. 189-190).

Conforme alerta Moretti, os sonhos disputam os limites entre mentira e verdade. Desponta um caráter híbrido, responsável por turvar a visão de quem almeja, articula e executa. Os sonhos podem adquirir o caráter de ilusão ou de alucinação.

Discutindo seu aspecto ilusório, Tereza Menezes relembra que boa parte do trajeto dos motes proveio das transformações econômicas e sociais amplamente discutidas pela burguesia e transportadas às peças de Ibsen:

Essas infindáveis discussões nos cafés e nas salas de visita da época foram instigadas pelo efeito desorganizador de suas peças, da forma como os acontecimentos se sucedem, fazendo o público organizar seus juízos em uma determinada direção e, ao mesmo tempo, focando a situação do ponto de vista das motivações mais genuínas do personagem. Além dos casos de Nora e Brand, já citados, podemos lembrar também de John Gabriel Borkman. Ele deu desfalque, foi preso, traiu a mulher que amava; tudo isso nos leva a considerá-lo um perigoso "mau caráter". No entanto, a paixão pelo seu sonho de construir um império, e dar trabalho digno para Revista (Entre Parênteses)

Número 9, Volume 1, 2020 - ISSN 2238-4502 


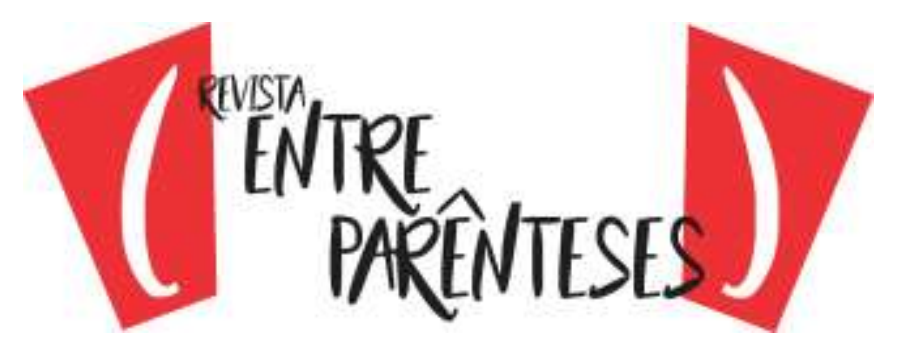

milhares de pessoas, torna impossível não admirar a obstinação e a grandeza desse homem. (MENEZES, 2006, p. 71).

A discussão sobre o ethos de Borkman avança sobre o plano de conteúdo: "Nunca houve tanta discussão dentro e fora do palco sobre os valores básicos da cultura como casamento, papéis sociais, desejos pessoais, os limites da verdade, o ético e o estético como balizadores de atitudes e muitos outros." (MENEZES, 2006, p. 71). Discutem-se os limites éticos. O efeito organizador da peça conduziria o espectador a proclamar a condenação do banqueiro, todavia, como condenar alguém que, além de não roubar, buscava a felicidade?

Se a ilusão não contém, em si, o ranço da maldade, da desonestidade e da falcatrua, seus efeitos são devastadores. As condenações social e judicial são implacáveis, esterilizando qualquer possibilidade de retorno ao convívio comunitário.

Por um lado, se os limites entre verdade e mentira que constituem os sonhos são discutíveis e, se inaceitáveis, põem o espectador/leitor na faculdade de abrir exceção contra a prática de erros, de outro, o desvio da ilusão pode entrar na alucinação. A alucinação manifestar-se-ia por seu atrelamento total ao erro, de modo pejorativo e indesculpável, aproximando-se da imaturidade ou da patologia. A alucinação resultaria dos entraves do homem com o mundo em transformações que superam sua capacidade de compreensão dos novos patamares, regras e limites. $O$ homem do século XIX, em que podemos inserir Borkman, perde a noção de sua força e de sua capacidade de mudança, em um mundo cientificista, capitalista e industrializado, cujos esforços confluem na tentativa de domar não apenas o homem, mas também a natureza:

A primeira modernidade foi o período de novas descobertas e grandes avanços nas ciências naturais. A natureza era percebida como um fenômeno exterior à sociedade. O desenvolvimento da tecnologia e da indústria estava ligado ao domínio humano da natureza e à capacidade de extrair recursos naturais entendidos como eternos. Desse modo, a primeira modernidade implicou a ascensão de um dinamismo industrial baseado nos recursos naturais, aparentemente ilimitados. Nos dramas de Ibsen, as Revista (Entre Parênteses)

Número 9, Volume 1, 2020 - ISSN 2238-4502 


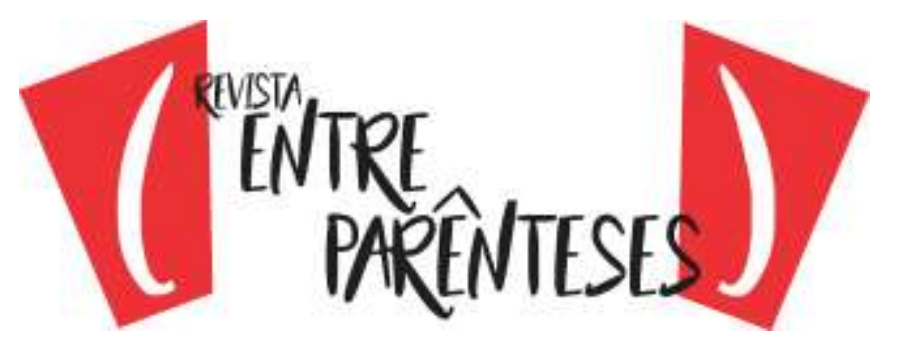

consequências trágicas de uma tal atitude estão expressas na última cena de John Gabriel Borkman (1896), onde o protagonista, que não tinha nenhum poder, apresenta uma visão de um futuro em que o domínio humano da natureza é somente uma alucinação. (RONNING, 2008, p. 33-34).

O domínio da natureza, por conseguinte, não é um sonho ou ilusão, mas uma alucinação que atinge Borkman em sua visão equivocada de comportamento altruísta que beneficiaria a humanidade. Domar a natureza "selvagem" seria um passo, contudo, domar a natureza interior do indivíduo, levando-o a entender os impedimentos reais que recaem sobre seus projetos, parece atividade inútil nessa personagem, a qual permanece sem compreender os mecanismos do mundo que a cerca.

O ex-banqueiro percorre o trajeto da ilusão, do perdão e da reabilitação. No segundo ato, conversando com seu amigo Foldal, aspirante a ficcionista, acredita na fundação de um banco cujos diretores implorarão para que forneça as diretrizes da empresa, reabilitando-o ao mundo dos negócios e ao convívio social:

BORKMAN, avecun geste de lamain: Reste doncassis. (De plusenplusexcité.) Lorsquel'heure de laréhabilitationsonnerapour moi... Quandilsaurontcompris que l'onnepeut se passer de moi... quandilsviendrontici me trouverdanscettesalle... etqu'ilsramperonten me suppliant de reprendrelesrênes de la banque!... Cette nouvelle banque, qu'ilsontfondée... etqu'ils ne saventpasdiriger... (II se poste prèsdu bureau commeprécédemment et se frappelapoitrine.) Je me tiendraiici pour les recevoir! Et l'onentendra, l'onapprendra par tout le pays quelles conditions pose John Gabriel Borkman pour... (II s'arrêtesoudainetregardefixementFoldal.) Tu me regardes avecunair de doute! Tu necroispeut-êtrepasqu'ilsviendront? Qu'ilfaudra, faudra, faudraqu'ilsviennent à moi unjour? Tu nelecroispas!

FOLDAL: Si, jelecrois, Dieusait, John Gabriel.

BORKMAN, se rassoitsurle canapé: Moi, jelecroisfermement. Je sais avec une inébranlable... qu'ilsviendront... Si jen'avais eu cettecertitude... il y a longtemps que je me seraistiré une balledanslatête. (IBSEN, 2006b, p. 1597) ${ }^{18}$.

\footnotetext{
18 BORKMAN, com um gesto de mão: Permaneça então sentado. (cada vez mais excitado.) Quando a hora da reabilitação soar para mim... Quando eles terão compreendido que não podem ficar sem mim... Quando eles virão aqui me procurar nesta sala... E que eles suplicarão para que eu tome as Revista (Entre Parênteses)
}

Número 9, Volume 1, 2020 - ISSN 2238-4502 
Foldal não ridiculariza o amigo que, inclusive, o arruinou financeiramente. No entanto, discerne, no discurso, a ilusão da realidade. Obviamente, ninguém se arriscaria no envolvimento com um condenado, cuja suposta genialidade não apagaria seu passado atrás das grades. Mais adiante, indagado novamente sobre sua confiança na absolvição de Borkman, Foldal sai pela tangente: "Il n'y a pas de jurisprudencepourdeschosespareilles."19 (IBSEN, 2006b, p. 1602).

Em discussão com a esposa, na frente da cunhada Ella, pulsa ainda a ilusão de ambição e poder. Acredita-se responsável pela distribuição da felicidade. Entretanto, a que espécie de felicidade se refere, se nunca dedicou a mínima parte dela ao filho?

MADAME BORKMAN, évasive, avec um geste de lamain: Tu n'as jamais rienaiméendehors de toi-même... voilàlecoeurdusujet.

BORKMAN, fièrement. J'aiaimé le pouvoir...

MADAME BORKMAN: Le pouvoir, oui!...

BORKMAN: ... le pouvoir de créer du bonheur tout autour, tout autour de moi!

MADAME BORKMAN: Tu as euun jour le pouvoir de me rendreheureuse. T'enes-tuservi?

BORKMAN, sans la regarder: D'ordinaire, ilfaut que quelqu'unsuccombe... dans un naufrage.

MADAME BORKMAN: Et tons fils! As-tu employétonpouvoir... oubien as-tu vécu et respirépourlerendreheureux?

BORKMAN: Lui, jeneleconnaispas.

MADAME BORKMAN: Non, c'estvrai. Tu neleconnaismêmepas. (IBSEN, 2006b, p. 1619) ${ }^{20}$.

rédeas do banco!... Esse novo banco, que eles fundaram... e que eles não sabem dirigir... (Ele se coloca perto da mesa, como antes, e bate no peito.) Eu estarei aqui para recebê-los. E se perceberá, se espalhará para todo o país quais as condições de John Gabriel Borkman para... (ele para de repente e olha fixamente Foldal.) Olha-me com um ar de dúvida! Não acredita que eles venham? Mas é preciso, é preciso, será necessário que eles venham até mim um dia, não? Você não acredita!

FOLDAL: Sim, eu acredito, por Deus, John Gabriel!

BORKMAN, no sofá: Eu creio firmemente. Eu sei com uma inquebrantável... que eles virão... Se eu não tivesse essa certeza... há muito tempo eu teria metido uma bala na cabeça.

19 "Não há jurisprudência para coisas semelhantes."

20 MADAME BORKAM, reticente, com um gesto de mão: Jamais amou nada além de você mesmo... essa é a questão.

BORKMAN, orgulhosamente: Eu amei o poder...

MADAME BORKMAN: O poder, sim!...

Revista (Entre Parênteses)

Número 9, Volume 1, 2020 - ISSN 2238-4502 
O distanciamento concretizar-se-ia mais adiante, quando, convocado pelo pai para ajudá-lo em sua retomada ao convívio social, enfrentando torcida contrária (mãe) e favorável (tia), Erhart recusa-se a ajudar na reabilitação do financista:

BORKMAN: Me réhabiliter, voilàce que jeveux. Recommencerà partir de tout enbas. Ce n'est que par son présentet son avenirqu'un homme peutexpier son passé. Entravaillant... entravaillantconstamment à tout ce qui, dans ma jeunesse, m'apparaissaitcomme la vie même. Mais qui, à presente, est de milliers de foisplushautqu'alors. Erhart... veux-tu êtreavec moi et m'aider à menercettevie nouvelle?

MADAME BORKMAN, levant la main ensigned'avertissement: Ne fais pas cela, Erhart.

ELLA RENTHEIM, chaleureusement: Si, si, fais-le! Oh! Aide-le, Erhart!

[...]

ERHART, accablé: Père, je ne le peux pas. C'esttout à fait impossible.

BORKMAN: Mais qu'est-ce que tu veuxenfin de compte?

ERHART, éclatant: Je suis jeune! Jeveuxvivremavie, mois aussi! Jeveuxvivremaproprevie! (IBSEN, 2006b, p. 1624) ${ }^{21}$.

Realçam-se os conflitos de Borkman pelas tentativas frustradas de se compreender, se explicar e, consequentemente, explanar aos outros sua perspectiva

BORKMAN: ...o poder de criar a felicidade de todos em volta, todos em volta de mim.

MADAME BORKMAN: Você teve um dia o poder de me fazer feliz. Fez?

BORKMAN, sem olhá-la: De modo geral, é necessário que alguém sucumba... em um naufrágio.

MADAME BORKMAN: E seu filho! Empregou seu poder... ou ao menos viveu e se esforçou para fazê-lo feliz?

BORKMAN: Não o conheço.

MADAME BORKMAN: Não, é verdade. Você não o conhece mesmo.

${ }^{21}$ BORKMAN: Reabilitar-me é o que quero. Recomeçar de baixo. É apenas no presente e no futuro que um homem pode expiar seu passado. Trabalhando... trabalhando constantemente em tudo o que, na minha juventude, me parecia vida de fato. Mas que, no presente, é milhares de vezes mais grandioso do que naquela época! Erhart... Quer estar comigo e me ajudar a liderar essa nova vida?

MADAME BORKMAN, levantando a mão, em sinal de advertência: Não faça isso, Erhart.

ELLA RENTHEIM, calorosamente: Sim, sim, faça! Oh! Ajude-o, Erhart.

$[\ldots]$

ERHART, abatido: Pai, eu não posso. É absolutamente impossível.

BORKMAN: Mas, afinal de contas, o que você quer?

ERHART, cintilante: Eu sou jovem! Eu quero viver minha vida, eu também! Eu quero viver minha própria vida!

Revista (Entre Parênteses)

Número 9, Volume 1, 2020 - ISSN 2238-4502 


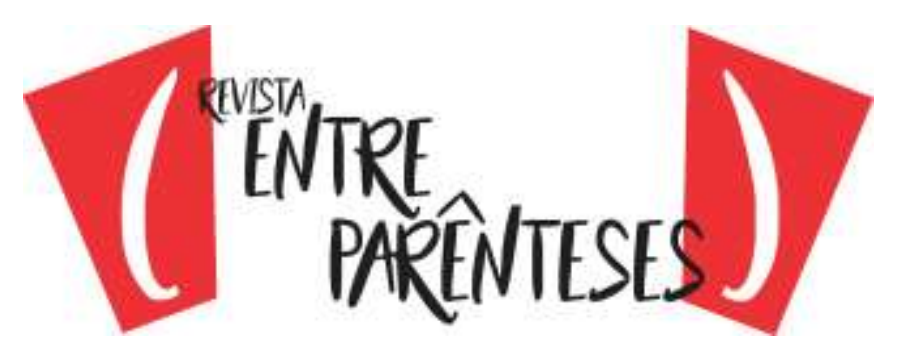

de vida, já que nem seu único amigo, nem sua esposa, nem sua cunhada conseguem assimilar sua percepção de felicidade e prazer, mistura que deixou praticamente a todos - amigo, esposa e cunhada - marcados por dor, tristeza e mágoa. A concepção social exige a confluência de dois mundos - 0 antigo e o atual - que se mesclam e resultam em nova estrutura, na qual seu filho transita com facilidade, mesmo escandalizando os familiares:

A primeira modernidade implica o desenvolvimento de uma sociedade capitalista baseada no trabalho salarial e na produção de mercadorias. O resultado desse processo foi uma situação de claras divisões e de ambientes proletários e burgueses com "mundivivências" diferentes. Isso contribui para a formação de um indivíduo moderno, cujas experiências estavam ligadas a grupos sociais distintos, criando um novo tecido social. A despeito disso, Ibsen não forneceu visão abrangente da sociedade moderna, no seu todo. Ele escavou profundamente dentro da vida psicológica e da vivência do mundo burguês em todos os seus dramas sobre a vida contemporânea. [...] É uma peça sobre poder. Esse tema também está no centro de John Gabriel Borkman, que trata das fantasias de poder de um homem sem poder nenhum. Em John Gabriel Borkman, o jogo de finanças e negócios existe à custa da humanidade real. Ele está disposto a vender o seu amor para atingir os píncaros do poder. (RONNING, 2008, p. 35).

Os problemas interiores das personagens de lbsen provêm dos embates sociais e das experiências pessoais. Passam longe da eventual explicação de desajuste psicológico congênito. Especificamente no caso de Borkman, sua vida se estabeleceu na modernidade dividida em "ambientes proletários e burgueses". Assim, Jacques De Decker (2006, p. 177) salienta a trajetória que o impulsionou da condição de filho de mineiro (ambiente proletário) ao cargo de diretor de banco (ambiente burguês).

Borkman ilude-se, ao pensar na possibilidade de "[...] criar uma existência harmoniosa e segura de um mundo incoerente" (RONNING, 2008, p. 37). Em sua visão, pairam diferentes realidades. Após sair de uma prisão (estatal/judicial) e meter-se em outra (no primeiro andar de sua casa), o banqueiro se revela confuso, 


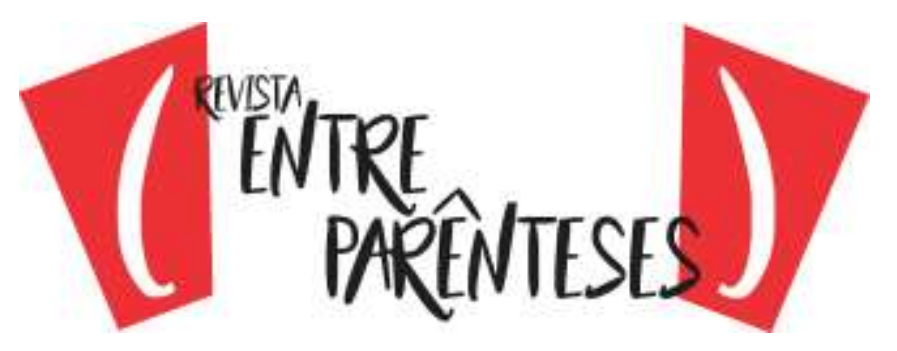

ao tentar, sem sucesso, aplicar os valores do passado às perspectivas do presente. Por essa razão, ilude-se, ao cogitar a possibilidade de amenizar as desgraças e promover a felicidade.

A burguesia e o proletariado são dois mundos diferentes, os quais exigem táticas capazes de desprender-se de um para inserir-se no outro. Ou, conforme salienta Ronning (2008, p. 35), pressupõem a assimilação de regras próprias na constituição de um "novo tecido social". Porém, essas regras devem mostrar ao indivíduo que ele não é nem burguês nem proletário, mas novo elemento passeando em um entre-lugar.

A condenação demonstra o repúdio do mundo burguês - detentor do capital e dos meios de produção - às tentativas de libertação do proletariado. Borkman transita nesse mundo, todavia, aproxima-se mais da configuração de intruso do que de integrante: ele não tem poder, mas fantasias, sonhos e ilusões que o empurram ao alheamento e ao devaneio. O recurso de escapar da realidade parece muito comum às personagens masculinas dos dramas interiores. A realidade objetiva torna-se um perigo; a subjetiva, um alívio. Assim, Solness (1960c), Ekdal (1960b) e Borkman procuram escapar do mundo real e objetivo.

Solness tenta despistar o avanço da idade, a ascensão profissional de seu empregado e seu medo de altura, mantendo-se preso ao escritório: reprova projetos, envolve-se com a empregada, manipula a esposa. Quando ele se aventura a fugir dos limites físicos, entrega-se à morte, depois de desequilibrar-se numa torre.

Do começo ao fim, Ekdal mantém sua rotina de providenciar cópias de documentos regularmente entregues ao escritório do antigo sócio, de conviver com a neta, a nora e o filho e, todos os dias, sempre que possível, de passear no sótão de sua casa, onde cria animais - entre eles, um pato selvagem ferido e domesticado. A entrada no sótão conduz ao mundo da fantasia em que o ex-tenente, repudiado pela sociedade, recobra sua vida ativa de oficial. Lá, ele se imagina numa floresta em que a caça ocorre pelos tiros disparados com ou sem a ajuda do filho. 


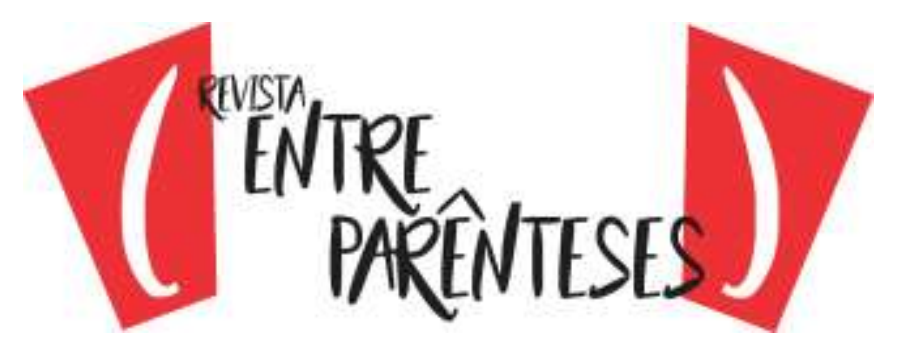

Borkman também entra no mundo de fantasias. Assim como as demais personagens masculinas mencionadas, faltam-lhe alternativas suficientes de execução desses planos:

Borkman renuncia ao amor em prol do ouro [...], é preso, confina-se em casa por mais oito anos e, no arrebatamento de sua visão, se expõe ao tempo gelado para uma morte certa. É por isto que o empreendedor é tão importante para o lbsen tardio: ele reintroduz a arrogância no mundo, e daí a tragédia. Ele é o tirano moderno: em 1620, o título de John Gabriel Borkman teria sido A tragédia do banqueiro. A vertigem de Solness é o símbolo perfeito desse estado de coisas: a desesperada tentativa do corpo de preservar-se da ousadia fatal que se exige de um fundador de reinos. Mas o espírito é demasiadamente forte: Solness vai subir a topo da casa que acabou de construir, desafiar Deus [...], acenar para a multidão embaixo e... cair. (MORETTI, 2014, p. 190-191).

Solness subiu ao topo de sua construção e, diante da imensidão, despencou à morte. Ekdal alimentou o sonho de se tornar um grande industrial - ou, pelo menos, um homem rico em sua sociedade com Werle - contudo, embaralhouse em seus passos e sucumbiu à ruína financeira e profissional. Borkman ascendeu financeira, social e profissionalmente, deixando para trás a vida de filho de mineiro, de sorte a alcançar a de chefe de banco, mas sucumbiu sem conseguir levantar-se:

$\mathrm{Na}$ última fase de sua obra, a dos dramas interiores, lbsen mergulha fundo nas fragilidades, culpas e ilusões do ser humano. [...] há uma constante: os protagonistas são homens que se frustraram com os rumos que tomaram as suas vidas, constatando que não viveram os seus reais desejos e que, de certa forma, já estão mortos ou alheios às suas questões vitais. (MENEZES, 2008, p. 50).

Algumas personagens masculinas provocarão o benefício da dúvida sobre o resto de sua existência, aguçando-nos a curiosidade a respeito de que rumos tomaram (agraciados pela felicidade ou cortados pela tristeza?); entre eles, poderíamos destacar Helmer (Casa de bonecas), Ekdal ou Werle (O pato selvagem) ou Tesman (Hedda Gabler). Obtiveram o privilégio de se articular, depois de enfrentar seus obstáculos?

Revista (Entre Parênteses)

Número 9, Volume 1, 2020 - ISSN 2238-4502 


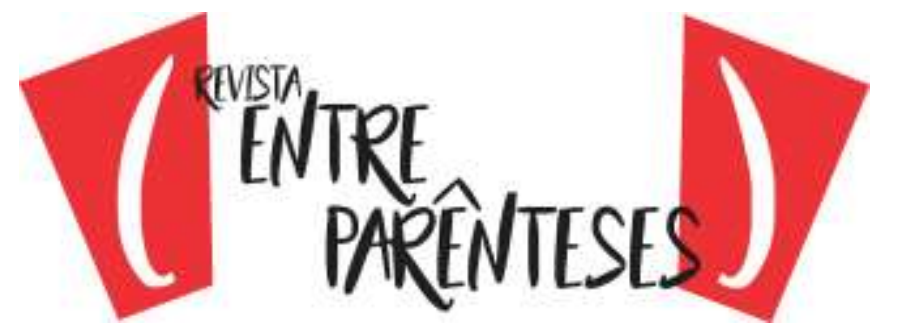

Mas muitos personagens de Ibsen não tiveram essa chance de reorganizar a sua subjetividade, de modo a poder conviver com tal angústia. Tipos como Brand, ou John Gabriel Borkman, não tiveram o benefício da dúvida, de lidar com o indeterminável e o contraditório. Eles foram impelidos por uma força interior, que não conhecia nuances na busca obsessiva de seus fins, e trataram seu desejo de grandeza como uma necessidade objetiva e absoluta; empenharam a sua vida - e de outros à sua volta - para tentar satisfazê-la. Foram incapazes de conviver com as limitações que o mundo impõe ao querer humano. (MENEZES, 2008, p. 53).

John Gabriel morre na noite de inverno. Uma mão esmaga seu coração. Provavelmente, acometido de um infarto fulminante. Com ele, finda-se a loucura individual de restabelecimento de um mundo feliz e fundam-se duas novas realidades entrelaçadas: Madame Borkman e Ella. Ambas encerram o drama confessando a solidariedade, no momento em que, tomando conhecimento da morte do banqueiro, se reconhecem como suas sombras. Com a morte dele, acaba-se uma loucura de sombras, iniciam-se duas novas realidades?

\section{REFERÊNCIAS}

CISNE, Mirla. Feminismo e consciência de classe no Brasil. São Paulo: Cortez, 2014.

DECKER, Jacques de. Ibsen. Paris: Gallimard, 2006.

FALQUET, Jules. Pour une anatomie des classes de sexe: Nicole-Claude Mathieu ou la conscience des oprimés. Cahiers du genre, v. 50, p. 1-25, 2015.

GASSNER, John. Ibsen, o viking da dramaturgia. In: . Mestres do teatro II. São Paulo: Perspectiva, 2003, p.1-36.

GUILLAUMIN, Colette. Práctica del poder e idea de Naturaleza. In: GUILLAUMIN, Colette; TABET, Paola; MATHIEU, Nicole Claude. El patriarcado al desnudo. Buenos Aires: Brecha Lésbica, 2005, p. 19-56.

IBSEN, Henrik. A dama do mar. In: 1960a, p. 395-473. . Seis dramas. Porto Alegre: Globo, 


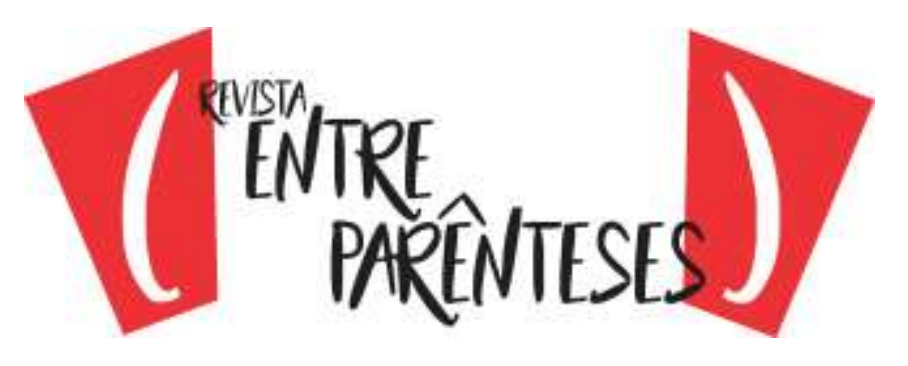
207-300.

O pato selvagem. In: . Seis dramas. Porto Alegre: Globo, 1960b, p.

. Solness, o construtor. In: . Seis dramas. Porto Alegre: Globo, 1960c, p. 491-562. $\overline{1675-1751 .}$

Hedda Gabler. In: Teatro completo. Madrid: Aguillar, 1973, p. . Um inimigo do povo. Porto Alegre: L\&PM, 2002.

Hedda Gabler. In: . Théâtre. Paris: Gallimard, 2006a, p. 1337-1421.

John Gabriel Borkman. In: . Théâtre. Paris: Gallimard, 2006b, p. $\overline{1569-1644 .}$

Casa de bonecas. Mairiporã: Veredas, 2012.

MELLO, Luiz Carlos Migliozzi Ferreira de. Sobre a semiótica das paixões. Signum: estudos da linguagem, Londrina, n. 8/2, p. 47-64, dez. 2005.

MENEZES, Tereza. Ibsen e o novo sujeito da modernidade. São Paulo: Perspectiva, 2006.

A elaboração de uma nova subjetividade nos personagens de Ibsen. In: SCHOLLHAMMER, Karl Erik (Org.). Henrik Ibsen no Brasil. Rio de Janeiro: PucRio/7letras, 2008, p. 49-55.

MORETTI, Franco. O burguês. São Paulo: Três Estrelas, 2014.

RONNING, Helge. Henrik Ibsen como agente da modernização: enfoque em A casa de boneca e O pequeno Eyolf. In: SCHOLLHAMMER, Karl Erik (Org.). Henrik Ibsen no Brasil. Rio de Janeiro: PucRio/7letras, 2008, p.31-47.

RYNGAERT, Jean-Pierre. Introdução à análise do teatro. São Paulo: Martins Fontes, 1996.

SCHOLLHAMMER, Karl Erik (Org.). Henrik Ibsen no Brasil. Rio de Janeiro: PucRio/7letras, 2008a.

As últimas peças de Henrik Ibsen. In: SCHOLLHAMMER, Karl Erik (Org.). Henrik Ibsen no Brasil. Rio de Janeiro: PucRio/7letras, 2008b, p. 81-87. 


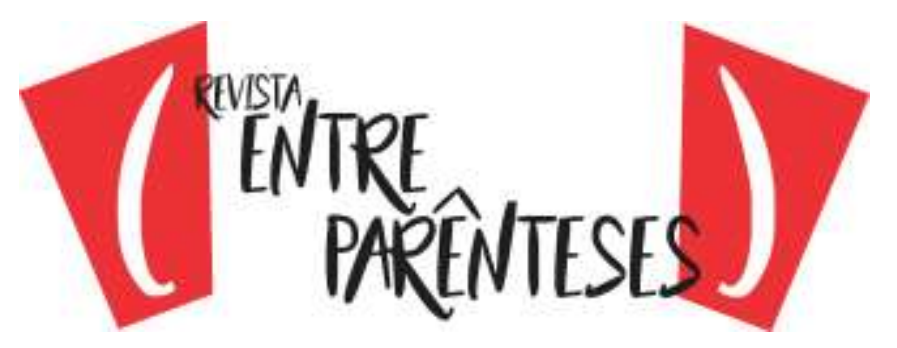

SILVA, Jane Pessoa da. Ibsen no Brasil: historiografia, seleção de textos críticos e catálogo bibliográfico. 2007. 612 f. 3 v. Dissertação (Mestrado em Teoria Literária e Literatura Comparada) - Faculdade de Filosofia, Letras e Ciências Humanas, Universidade de São Paulo, São Paulo, 2007.

Breve panorama de Ibsen no Brasil. In: SCHOLLHAMMER, Karl Erik (Org.). Henrik Ibsen no Brasil. Rio de Janeiro: PucRio/7letras, 2008, p. 11-29.

SILVA, Vicentônio Regis do Nascimento Silva. Continuidade e ruptura: a dominação masculina na dramaturgia de Tchekhov e Ibsen. RevLet - Revista Virtual de Letras, Jataí, v. 8, n.1, p. 751-763, jan./jul. 2016.

SPIVAK, Gayatri Chakravorty. Pode o subalterno falar? Belo Horizonte: Editora UFMG, 2010.

Recebido em: 20/04/2020

Aceito em: 17/08/2020 